\title{
ROJO GRAFITADO: PRODUCCIÓN DE UN ESTILO DE CERÁMICA FINA TEMPRANA EN LOS ANDES
}

\author{
Isabelle Druc a \\ Silvana Bertolino ${ }^{b}$ \\ Andrée Valley ${ }^{c}$ \\ Kinya Inokuchi ${ }^{\mathrm{d}}$ \\ Francisco Rumiche ${ }^{\mathrm{e}}$ \\ John Fournelle ${ }^{\mathrm{f}}$
}

\begin{abstract}
Resumen
Durante el primer milenio a. C. aparecen en pocas cantidades botellas finamente decoradas de estilo Cupisnique Rojo Grafitado en varios sitios del Perú norcentral. El análisis petrográfico y con microscopia digital en luz reflexiva de la pasta, estudios quimicos de los pigmentos y estudios estilísticos sugieren que su producción fue hecha por alfareros especializados que compartían recetas de pasta y tecnología de manufactura, pero no recursos, y que trabajaban en distintos talleres. La composición mineral y la granulometría son similares, apuntando al uso de un temperante de roca intrusiva molida o de sedimentos ricos en fragmentos de rocas intrusivas y una mineralogía derivada de cuerpos del Batolito de la costa. Por sus diseños en negro brillante pintados sobre un engobe rojo muy pulido se le dio el nombre de Rojo Grafitado, pero estudios recientes demuestran que no todo lo negro es grafito. Un análisis con microscopio electrónico de barrido (MEB-EDS) muestra que en un caso el manganeso fue utilizado como pigmento, mientras que, en otros siete casos, fueron detectados picos altos de carbono, escaso hierro y no se ve manganeso. Esto sugiere que la superficie fue carbonizada en condiciones reductoras de quema. En Kuntur Wasi, el estilo Cupisnique Grafitado fue también imitado en otras formas $y$ variantes estilisticos.
\end{abstract}

Palabras clave: Cupisnique, cerámica, pigmentos, petrografia, $M E B$

${ }^{a}$ Department of Anthropology, University of Wisconsin-Madison

Correo electrónico: icdruc@wisc.edu

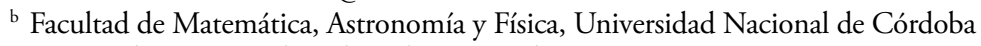

Correo electrónico: silvanabertolino@gmail.com

c Madison Area Technical College, en Madison, Wisconsin, EE.UU.

Correo electrónico: avalley@gmail.com

d Graduate School of Humanities and Social Sciences, Saitama University, Japan

Correo electrónico: inokuchi.kinya@gmail.com

e Ingeniería Mecánica, Pontificia Universidad Católica del Perú

Correo electrónico: frumiche@pucp.edu.pe

${ }^{\mathrm{f}}$ Eugene Cameron Electron Microprobe laboratory, Department of Geoscience, UW-Madison

Correo electrónico: johnf@geology.wisc.edu 


\section{Abstract}

\section{THE ROJO GRAFITADO CASE: PRODUCTION OF AN EARLY FINE-WARE STYLE IN THE ANDES}

During the first millennium B.C. finely decorated Cupisnique Rojo Grafitado bottles appeared in small numbers on different sites of north-central Peru. Petrographic and portable digital microscopy of the paste, chemical analysis of the pigments, and stylistic studies point to a production in the hands of specialized potters sharing similar paste recipes and technology of manufacture, but not resources, and working independently in different workshops. Mineral composition and granulometry are similar for vessels found on different sites, pointing to the use of crush rock temper or sediments rich in intrusive rock fragments probably derived from outcrops in the northern coastal batholith. Shiny black designs over a highly polished red slipped surface gave the name to the style but recent analysis showed that not all designs were done with graphite. Scanning Electron Microscopy (SEM-EDS) analysis revealed that, at least in one case, the black pigment used for surface decoration was manganese, while in seven other cases high $\mathrm{C}$ peaks, low Fe peaks, and no $\mathrm{Mn}$ were detected. For these wares, this suggests surface carbonization in reduced conditions. In Kuntur Wasi, the Cupisnique Grafitado style was imitated on other forms and style variants.

Keywords: Cupisnique, ceramic, pigments, petrography, SEM

\section{Introduction}

During the first millennium B.C. finely decorated Rojo Grafitado globular, stirrup-spout bottles appeared in small numbers in sites of the north-central coast and highlands of Peru. The style name derives from their bright red polished slip and black shiny designs, and is related to the Cupisnique ceramic tradition, which developed on the northern coast of Peru, north and south of the Cupisnique Quebrada (Larco Hoyle 1941; Elera 1998; Toshihara 2002; Sidoroff 2005; Nesbitt 2012; Burtenshaw-Zumstein 2014). Whole vessels and fragments have been reported in burial and ceremonial sites in the Jequetepeque-Tembladera, Cupisnique, Moche and Nepeña Valleys, and further south, as looted material, but also from secure contexts such as Cerro Blanco, Puémape, Kuntur Wasi, and Chavin de Huantar (Lumbreras 1993; Elera 1998; Ikehara and Shibata 2005; Onuki and Inokuchi 2011). Called Cupisnique Transitorio by Larco Hoyle (1941), their temporal assignation is now broadly set between 1200 and 500 BC (Burtenshaw-Zumstein 2014). In addition to a very distinctive style, the technology and paste recipe of these wares appeared to be similar in the cases observed and their provenance non local (Fig. 1; Druc 2014; Druc et al. 2017a). How can these similarities over great distances be interpreted? Was there an area of production from which the Cupisnique Rojo Grafitado bottles were distributed? Are we dealing with groups of specialists sharing a technological style but producing from different places? Could there be itinerant master potters producing those wares?

In terms of style and manufacture, the study conducted by Julia Burtenshaw-Zumstein showed that the Rojo Grafitado wares were built differently than other Cupisnique wares, in the way the spouts and stirrups were crafted and attached to the body, the overall shapes, and decorative techniques, and that they pertained to an aesthetic tradition of its own (Type 3 of her typology, 2014:223, 228). This style is fairly rare and represents about $5 \%$ of her Cupisnique assemblage (45/902, 2014: 446).

The compositional studies of Rojo Grafitado and Negro Grafitado wares presented here bring more data to the topic. In addition to paste analysis using thin section petrography (TSP) and portable digital microscopy (PDM) of cross sections, scanning electron microscopy with energy dispersive spectroscopy (SEM-EDS) was conducted on the pigments of eight Grafitado sherds from three sites: Puémape, on the coast south of the Jequetepeque Valley, Kuntur Wasi at 2300m in the Jequetepeque basin some $150 \mathrm{~km}$ away from Puémape, and from the Barbacoa cemetery in the lower Chicama Valley (Fig. 1). Firing tests were conducted to see how different black pigments would react under certain firing atmospheres. Due to space limitation these will only be reported 


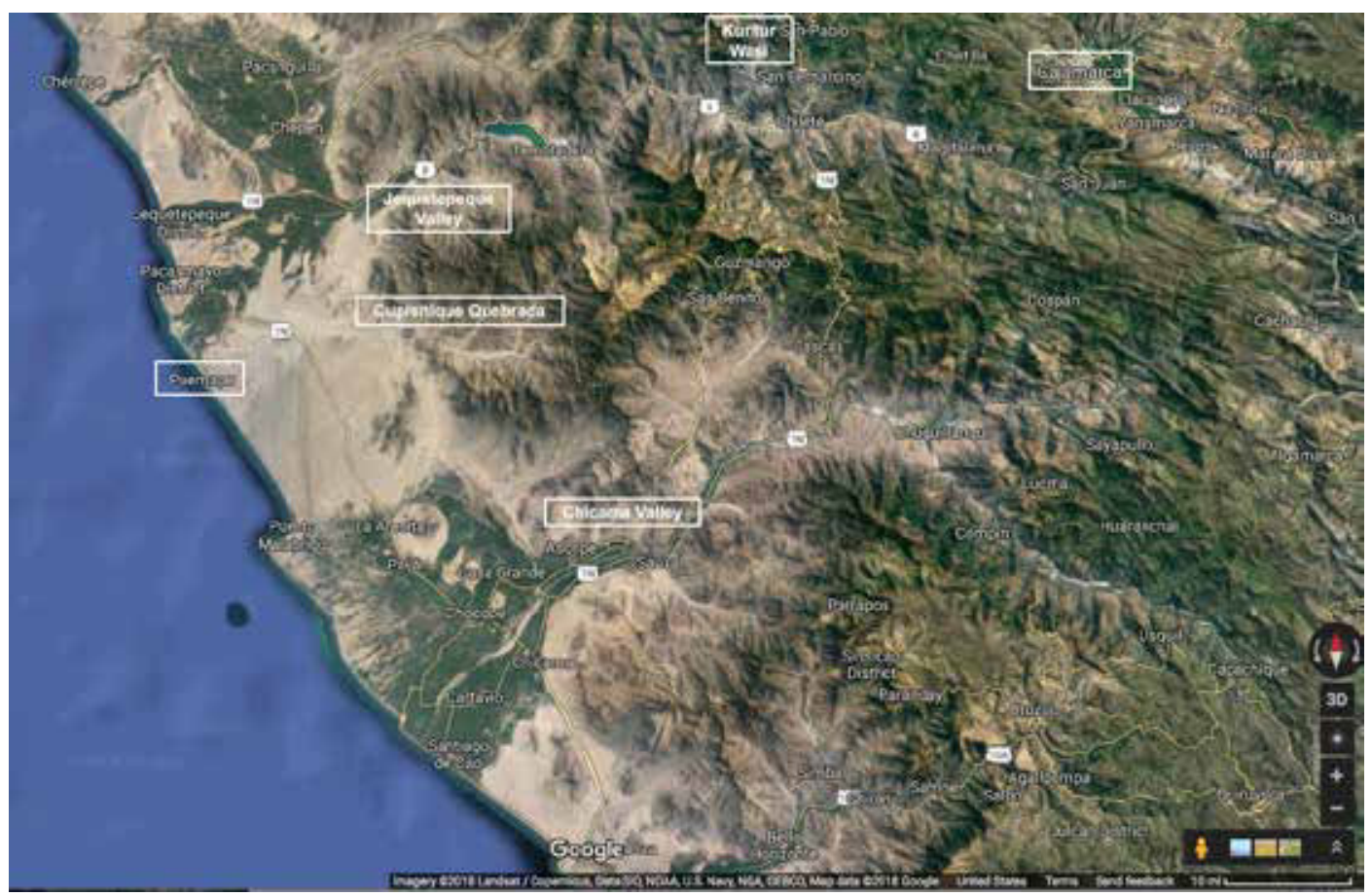

Figure 1. Google map of the study region, modified to show the location of the main sites discussed.

briefly in the discussion. The results of the initial petrographic studies are summarized below, followed by the presentation of the digital microscopy data, and SEM-EDS analysis. We will then discuss the results of the different analyses, seeking to propose production scenarios that could explain the technological similarities observed for these Rojo Grafitado vessels.

\section{Paste compositions of Cupisnique Grafitado wares from Kuntur Wasi and Puémape: petrographic analysis}

True Cupisnique Rojo Grafitado style bottles appear in very small numbers in Kuntur Wasi during the Idolo phase (950-800 BC). During the Kuntur Wasi phase (800-550 BC) bottles and bowls showing the use of black on red decoration are a little more frequent but vessel forms and surface finish are different (Inokuchi 2010; Onuki and Inokuchi 2011). Negro Grafitado wares, contrary to Rojo Grafitado ones, are only found during the KW phase and they are more common, while grafitado decoration is not found in later phases. The Grafitado fragments from Kuntur Wasi stand out not only for their style and rarity, but also for their composition characterized by the presence of medium to coarse, subangular to subround granitic to granodioritic clasts and derived rockforming minerals, a material foreign to the area (Druc et al. 2017a, b). The closest intrusive bodies of intermediate composition that could provide this type of assemblage are down in the Middle Jequetepeque Valley, as part of the Coastal Batholith that runs parallel to the Peruvian coast. This would suggest that the provenance of the three Idolo phase Rojo Grafitado fragments analyzed from Kuntur Wasi could be the Middle Jequetepeque Valley or another of the adjacent coastal valleys, and similarly for most Rojo and Negro Grafitado bottles from the Kuntur Wasi phase. The Rojo Grafitado bowls have less clear provenances, as their paste display also volcano-sedimentary materials that could be locally available. This type of material is ubiquitous in the sediments of the Jequetepeque Valley and close to Kuntur Wasi, and is thus not a good provenance marker. 
The Rojo Grafitado bottle fragment PU156 (Fig. 3b) from the coastal site of Puémape also stands out for its rarity among the rest of the Puémape collection and for its paste mineralogy (Druc 2014). The paste contains coarse angular to subangular granodiorite clasts, a material derived from intrusive-rich primary sediments, typically found in the coastal Batolith, and a recipe totally different from the littoral sand seen in the other Puémape ceramics.

\section{Paste composition of Cupisnique Rojo Grafitado bottles from the Larco Museum}

To verify if the paste characteristics observed for the Kuntur Wasi and Puémape fragments were repeated in other Rojo Grafitado vessels we turned to the Larco Museum in Lima, which hosts several Rojo Grafitado vessels of Cupisnique style as part of the 1936-1939 collection of Larco Hoyle. This collection is said to come from the burial sites of Barbacoa, Palenque and Santa Ana (hereafter Chicama bottles), and from nearby areas, in the lower Chicama Valley on the north coast of Peru. These pieces were off-limit in terms of petrographic analysis, and could not be transported to a laboratory. However, eight vessels were available to perform on-site examination of the paste with a portable digital microscope taking advantage of chipped areas (Fig. 2). The analysis was conducted in reflected light, contrary to a petrographic analysis using thin sections and working with transmitted light. The temper of these bottles is characterized by subangular minerals and rock fragments of medium to coarse granulometry, with lithoclasts of acid to intermediate igneous origin (probably of granitic to granodioritic composition), crushed, or from primary sediments. The lithoclasts are few, in a granular matrix with finer felsic and mafic crystals. Grain orientation differs, being in some cases parallel to the wall, in others with mix orientation, or following a circular pattern. The paste is oxidized. The texture and color of the clay matrix is different from one bottle to the next, and the mineralogy suggests the use of different quarries or deposits. Details of the paste analysis of the bottles examined are given in the appendix.

It was also possible to take micro-samples of the black pigment of five of the Chicama bottles for SEM-EDS analysis at the Pontificia Universidad Católica del Peru (PUCP) in Lima. These analyses are described in the next section.

From what could be observed, the paste recipe to produce the Chicama, Puémape and Kuntur Wasi Rojo Grafitado bottles analyzed seems very similar, as to temper material, way to prepare it, and firing atmosphere. It should be stated that petrographic analysis by Robert Ixer of one black burnished Cupisnique ware with red-filled incisions from Farfan in the Lower Jequetepeque Valley, as well as of sediments from the surrounding area failed to show this kind of mineral assemblage (Sidoroff 2005: 283-384). The sample analyzed by Ixer and the other Cupisnique fragments found at Farfan are not of Rojo Grafitado style, and their composition conforms to available local raw materials. Ixer's analysis reinforces the idea that the Rojo Grafitado style was produced with a different paste recipe than other Cupisnique style bottles.

\section{Pigment analysis of eight Cupisnique-style Grafitado wares with SEM-EDS}

The SEM-EDS analyses sought to identify the composition of the black pigment. This could reveal adherence to a technological tradition, since there are multiple ways to produce a black color on a ceramic surface. The first SEM analysis was conducted in 2014 at the SEM laboratory of the Department of Geoscience of the University of Wisconsin-Madison with a Hitachi S3400 VP and Thermo Electron NSS EDS system, with clay mineralogist Silvana Bertolino and John Fournelle, director of the laboratory. This analysis focused on the surface of Puémape bottle fragment PU156, Kuntur Wasi Rojo Grafitado bowl KW26, and Negro Grafitado bottle KW23. Isabelle Druc and Francisco Rumiche conducted additional analysis in 2015 with a Quanta 650 and EDAX program 

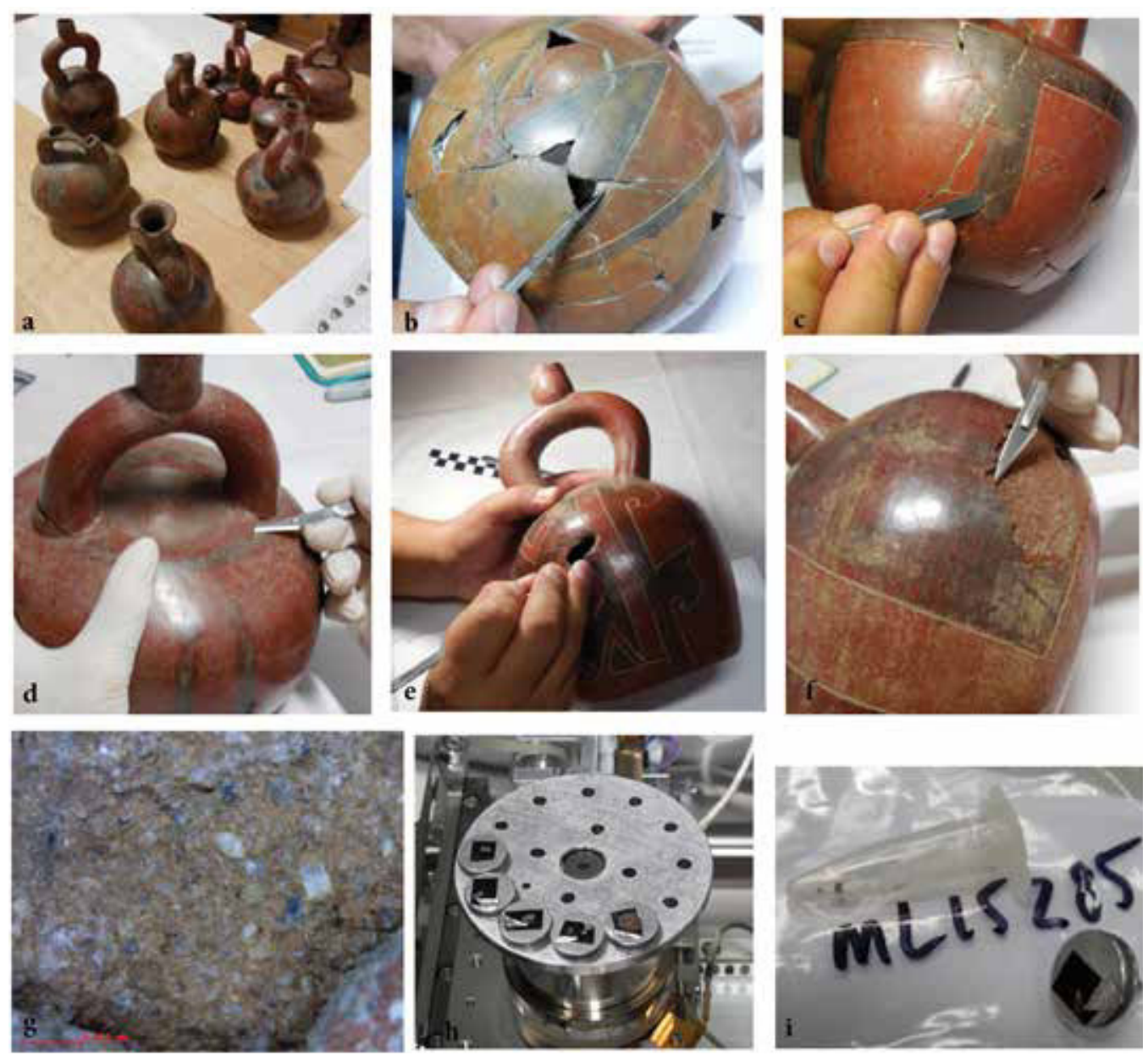

Figure 2. a. Larco Hoyle Cupisnique Rojo Grafitado vessels analyzed with digital microscopy; $b$-f bottles samples for pigment analysis: b-ML015284, c-285, d-289, e-292, f-294. g. Example of paste composition, bottle ML015294, DinoLite digital microscope, reflective light, scale bar $0.5 \mathrm{~mm}$. h-i. Pigment samples prepared for SEM-EDS analysis.

for elemental characterization, in the SEM laboratory of Mechanical Engineering at the PUCP, Lima, on black pigment samples of five Rojo Grafitado stirrup bottles from the Larco Museum in Lima. In both cases, area analyses were conducted in backscattering mode at $15 \mathrm{kV}$, in low vacuum, at different magnifications $(40 \mathrm{x}-2700 \mathrm{x})$ to obtain information on the chemical components present by their chemical contrasts. Using variable pressure, and because the fragments were supposed to have some carbon in their composition, the samples were metalized with gold at the Wisconsin laboratory and not metalized at the PUCP laboratory. In both laboratories, analysis time was 100 seconds using the EDAX program for elemental characterization.

a) Puémape Rojo Grafitado bottle PU156: The black pigment on this fragment (Fig. 3) was found to be rich in manganese $(22.5 \% \mathrm{MnO})$ and iron $\left(13.76 \% \mathrm{Fe}_{2} \mathrm{O}_{3}\right)$ and not in carbon (implying an absence of graphite). The red slip was rich in iron $\left(17.10 \% \mathrm{Fe}_{2} \mathrm{O}_{3}\right)$; its composition suggests that it corresponds to an iron rich clay. The white pigment in the thin line delineating the black design from the red slip was rich in calcium $(14.56 \mathrm{CaO})$, without carbon $(\mathrm{C})$, suggesting that we are in the presence of $\mathrm{CaO}$ and clay minerals probably in the form of calcite. The Ti peak observed might come from a contamination of the clay. The composition of the red slip overlaps 

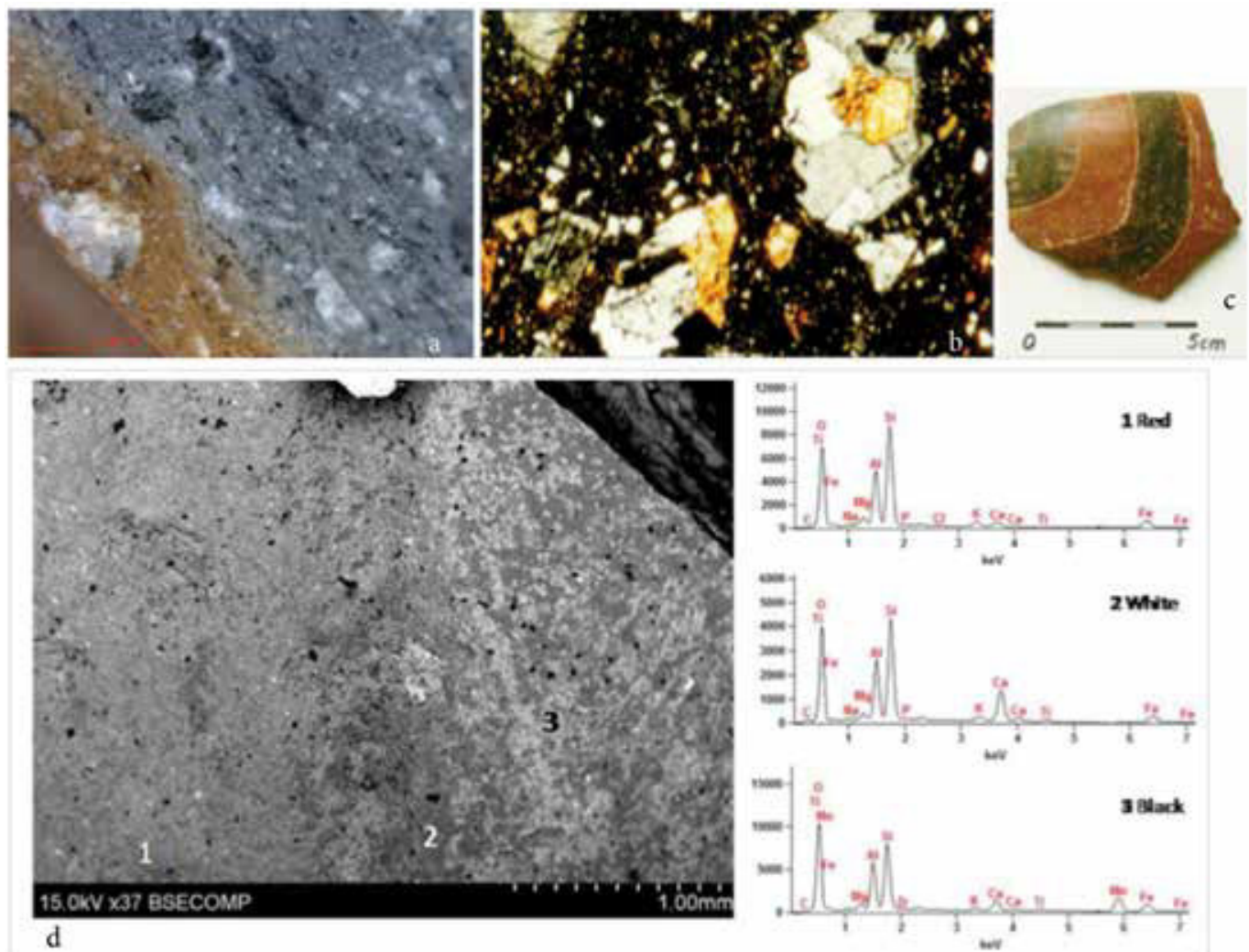

Figure 3. Puémape sample PU156, Cupisnique Rojo Grafitado bottle fragment. 3a Digital microscopy image of paste in reflective light, DinoLite portable microscope. 36 Photomicrogaph of the paste with granodiorite lithoclasts, transmitted light, $80 x \times p l .3 c$. Body fragment analyzed. 3d SEM-EDS image (back-scattering mode) and spectra for the red slip (1), white line (2), black pigment (3).

that of the other two paints in all spectra as it is observed by the occurrence of $\mathrm{Na}, \mathrm{Mg}, \mathrm{Si}, \mathrm{Al}, \mathrm{K}$, part of the Ca, Ti and Fe.

b) Kuntur Wasi Rojo Grafitado bowl KW26 and Negro Grafitado bottle KW23: The SEM-EDS analysis of the black pigment registered a medium $\mathrm{C}$ peak and no Mn peak, as well as peaks of $\mathrm{Si}$, $\mathrm{Al}, \mathrm{Mg}, \mathrm{Na}, \mathrm{K}, \mathrm{Ca}$, and Fe, elements that could pertain to the substratum or the clay base used for pigment application if such a base was used (Fig. 4).

c) The Cupisnique Rojo Grafitado bottles from Museo Larco: The black pigment of five bottles (ML015284, -285, -289, -292, -294) was collected in vials with the help of Ulla Holmquist and on-site technician. In the SEM-EDS analysis none of the samples showed Mn peaks. All displayed a high $\mathrm{C}$ signal, between 59\% and 81\% atomic weight, and low Fe peaks (below 1.5\% atomic weight), eliminating the possibility of having iron (in its reduced form) as the major element of the black color (Fig. 5).

In summary, all but the Puémape bottle fragment showed the presence of $\mathrm{C}$ as constituent of the black pigment. The black design of the Puémape bottle was produced with $\mathrm{Mn}$ or $\mathrm{Mn}-\mathrm{Fe}$ pigments. The carbon content of these wares does not necessarily imply the use of graphite and Raman spectrometry would be needed to identify it as such. The compositional differences and similarities observed are discussed next looking at production scenarios for the Cupisnique style vessels studied as well as other studies of black pigments in Andean ceramics. 

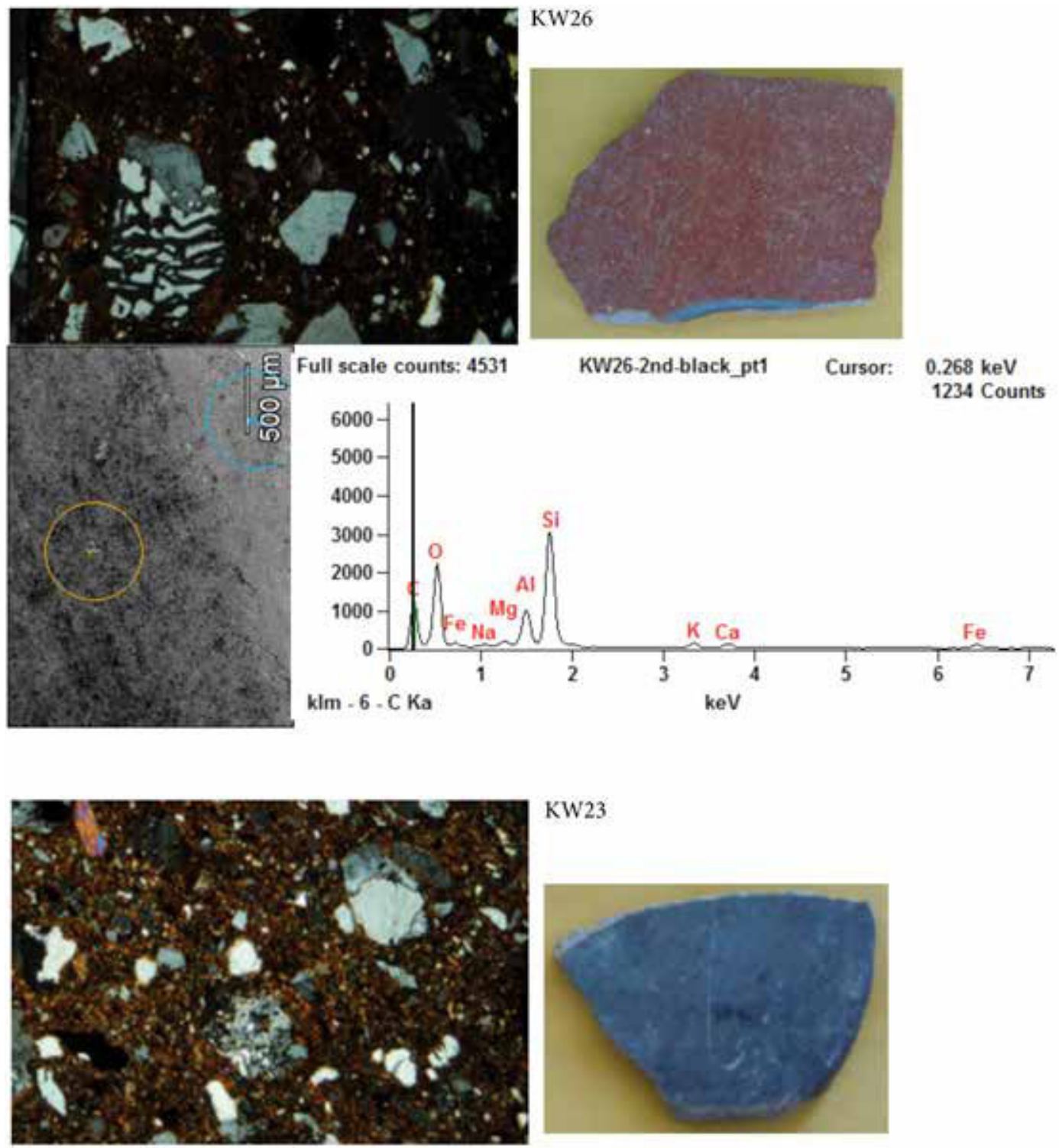

KW23

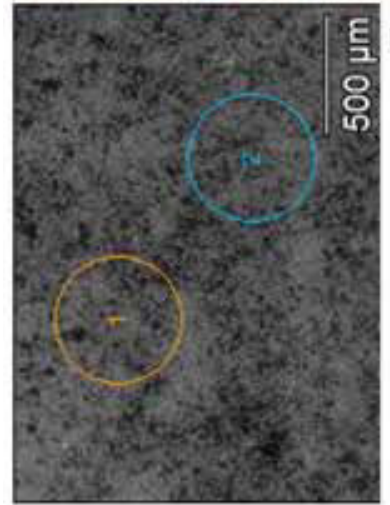

Full scale counts: 4531
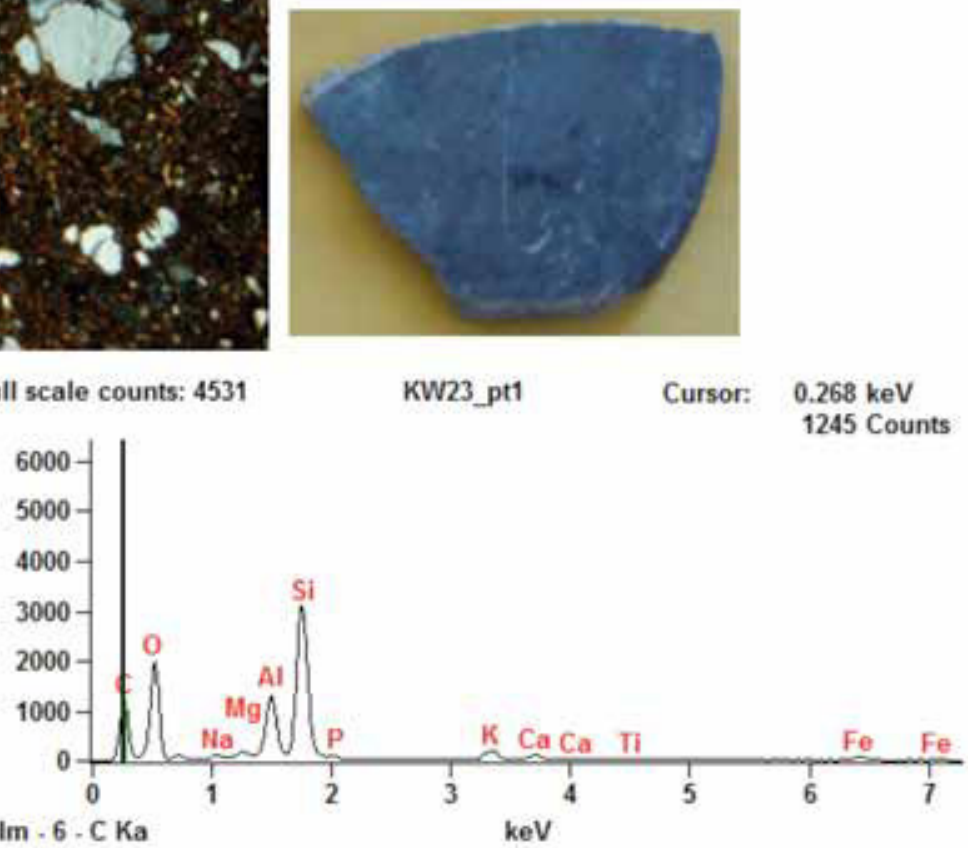

Figure 4. Bowl fragment Rojo Grafitado KW26, black pigment in groove (see arrow); and bottle base Negro Grafitado KW23. Photomicrographs of granitic paste, ceramic fragments, SEM-EDS image (back-scattering mode) and graphs of black pigment (1). 

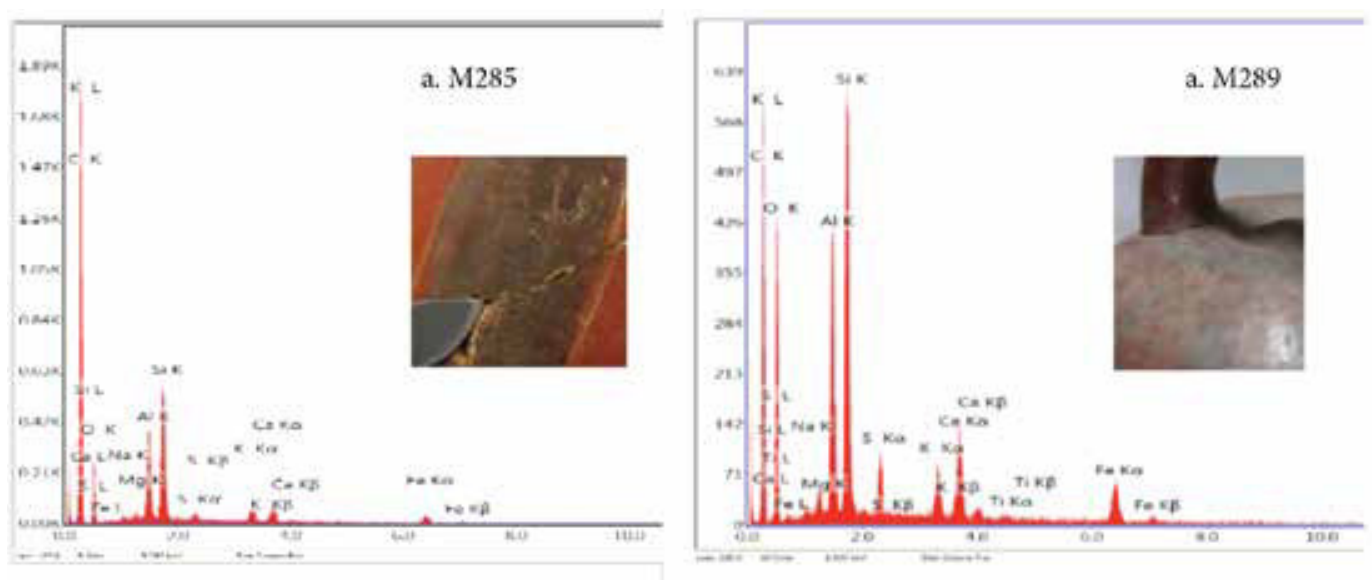

Figure 5. Examples of SEM-EDS spectra for the Chicama bottles ML015285 80\%C (a), ML015289 59\%C (b).

\section{Discussion}

Three lines of evidence suggest that the Cupisnique Rojo Grafitado vessels are the products of a particular technological tradition, with no centralized production but small workshops operating probably independently, while sharing recipe for composition, paste preparation, surface treatment and firing. 1) Paste analysis of Rojo Grafitado fragments identified the use of crushed granitic, granodioritic or dioritic temper, or of a sediment rich in these materials for all vessels analyzed what ever their findspot. These compositions are usually not local (in reference to the site the fragments were found). 2) Surface analysis by SEM-EDS showed that the black color can be the product of manganese application and not graphite (or resulting from surface carbonization). Carbon, however, remains the most frequent element present. Note that graphite, also called meta-anthracite, presents the highest grade of carbon. 3) The elaboration of these Rojo Grafitado wares was found to differ from the other Cupisnique wares as Burtenshaw-Zumstein notes (2014).

In term of provenance, the mineral composition of the Rojo and Negro Grafitado vessels analyzed show strong attributions to a low or mid-coastal valley area. Albeit displaying similarities due to the type of lithoclasts present in their paste, these Grafitado fragments show mineral and texture differences that suggest they were not made from the same material and probably not produced by the same workshops. This is also highlighted in the LA-ICP-MS study of ceramics from Kuntur Wasi, which included ten fragments of Rojo Grafitado and Negro Grafitado wares (Druc et al. 2017a).

The potters producing these bottles were apparently following the same recipe, which also called for using a coarse granular paste as none of the Grafitado pastes observed are fine. As nothing in craft production is careless, these choices probably relate to technical aspects of the production: too fine a paste might actually have been a hindrance to the production of these vessels, as clay retraction upon drying and firing could cause cracks, may be at least for the type of clays the potters were dealing with, such as one rich in illite and smectite as suggested by the EDS composition (with $\mathrm{Na}, \mathrm{Mg}, \mathrm{Ca}, \mathrm{K}, \mathrm{Fe}$ ). Furthermore as a slip covered the entirety of the vessel, a coarse paste would not show. In addition, these vessels were not destined for consumption (cooking, holding liquids, serving) but for ceremonial and burial use. This objective must have influenced their production, with emphasis on how the vessels look and not how they would withstand heat cycles or shocks.

As paste, surface treatment is a question of technological choice. Is the Puémape bottle for which $\mathrm{Mn}$ is used an exception? Does it singularize a workshop or production area? It must be 
noted that the execution of the design and incision of this Puémape bottle fragment is not as well done as on other bottles examined. Could this piece be the production of a less-skilled workshop or potter, not using the usual black pigment or firing process for this type of ware? Analyses of other Rojo Grafitado bottles found in Puémape need to be conducted to see if $\mathrm{Mn}$ use is actually more frequent there. However, manganese ore deposits are not reported in the area around Puémape. One source is known just south of Cajamarca, in the headwaters of the Jequetepeque, and the XRD analysis of a sample given by ceramist Lorenzo Cabrera from Cajamarca (Druc 2011) identified it as todorokite $\left(\mathrm{NaMn}_{6} \mathrm{O}_{12} 3 \mathrm{H}_{2} 0\right.$, analysis done at the University of Wisconsin-Madison in the Department of Geosciences). Sepulveda et al. (2013) note that in northern Chile, manganese deposits are only found in the high sierra. If this were the case for our study region, this would indicate that Mn oxide has been traded or brought back from the highland or high coastal valley, for a mid- or lower valley production and finally distributed or brought to Puémape on the coast.

Manganese is however not infrequent in ceramic production. It can be added to the paste to give a black body, used for pigment solo or, if mixed with iron, would have a blackening effect. It stays black or purple/black at most temperatures and atmospheres, even oxidizing (Shepard 1968; Clark 2001). Manganese was identified in pigments of Moche ceramics (Early Intermediate Period) by Del-Solar Velarde and colleagues (this volume), but in low percentages and not very frequently. It was also detected on Nasca wares (Early Intermediate Period) by Eerkens et al. (2014: 247) where the black pigment is high in $\mathrm{Mn}$, concentrated in clasts rich in Fe and $\mathrm{Mn}$ or manganese iron oxide. Manganese is also reported in several studies using a combination of techniques (Raman spectroscopy, SEM-EDS, XRD and petrography) of ceramics from Northwestern Argentina. For example, the black pigment of pieces of Aguada Ambato y Aguada Portezuelo styles are composed of Mn and Fe rich minerals such as Hollandite and Lithiophorite respectively (c. AD 500-950; Bertolino et al. 2009, 2011; Galvan Josa et al. 2009). In another study, the red, black, and brown pigments on the exterior surface of one Aguada bowl analyzed by De La Fuente et al. 2005 showed that the black pigment resulted from hematite fired in a reduced atmosphere $(72 \% \mathrm{Fe})$ with some manganese $(14 \%)$ in a coloidal clayey solution (7\% aluminosilicates). In a study of the same type of ceramics by Cremonte et al. (2003), the black pigment also contained Fe and $\mathrm{Mn}$ but in reverse proportions (Fe 12.06\%, Mn 28.64\%). Pigment analysis of late polychrome wares (900-1536 A.D. and later) from the Humahuaca Quebrada, Jujuy, and northern Puna, showed that the black pigment of the Puna samples was a compound of manganese $(\mathrm{Mn})$ and, in some cases, Jacobsite $\left(\mathrm{MnFe}_{2} \mathrm{O}_{4}\right)$. For the Humahuaca samples the black pigment was carbon $(\mathrm{C})$ and hematite $\left(\mathrm{Fe}_{2} \mathrm{O}_{3}\right)$ for some samples, and magnetite $\left(\mathrm{Fe}_{3} \mathrm{O}_{4}\right)$ in others (Acevedo et al. 2012, 2015; Marte et al. 2012). Finally, Puente and colleagues (2017) studying Belén ceramics of Regional Development Period (c. AD 1000-1600) have found $\mathrm{Mn}$ oxides, magnetite, titanomagnetite and graphite as components of the black pigment. These examples show the varied recipes potters could apply, even within the same region, and pigment use and firing should be seen as markers of a technological tradition rather than a functional choice.

Carbon is however the usual element found composing the black pigment of the Cupisnique Rojo Grafitado and Negro Grafitado vessels analyzed here with SEM-EDS. Without Raman spectrometry it is not possible to say that it is present as graphite. Note that graphite is quite common and can be found in different forms, crystalline to microcrystalline, while its oily feel and selflubricating property would facilitate rubbing it into a ceramic surface. It can also be produced upon firing in a reducing atmosphere, as shown in the archaeometric and experimental studies conducted by Izumi Shimada and colleagues (Shimada et al. 1994; Wagner et al. 1994; Shimada and Wagner 2001; Goldstein and Shimada 2007). These studies aimed at understanding how to produce the fully black Middle Sicán bottles, hallmark of the Huaca Sialupe workshops (AD 900-1100) in the Lower La Leche Valley. The authors successfully reproduced the process of carbonization and production of graphite on the vessels' surface from reduction firing in small tightly closed kilns. Contrary to the Sicán bottles, however, the paste of the Cupisnique bottles analyzed is not reduced. 
In firing experiments done by Valley and Druc (2017), the carbonization and reduction of the surface of experimental tiles coated with charcoal, graphite, manganese and hematite in a sigillata clay slip, and polished with a smooth rock, was achieved by transferring the tiles from a raku kiln into a barrel full of sawdust which the red hot tiles ignited. A lid was then put on the barrel to promote carbonization on the surface of the tiles. After about 10 minutes, the tiles were transferred to a pail of water to 'freeze' the carbonization process, but they could also have been left in the barrel with the lid closed until cool with the same effect. The different pigments coating the tiles showed different depth of penetration of the carbonization process, opacity, and limits with the clay body that should allow identification of the type of pigment used in thin section petrography (Fig. 6a-b). The results showed that: 1) a $\mathrm{MnO}_{2}$-slip is nearly opaque (in thin section) and presents a well defined border with the body; 2) a graphite-slip does not show opacity, it allows for a greater reduction zone than manganese and the limit between body and pigment is less well defined; 3) both coatings present inclusions protruding from the layer underneath or pertaining to the clay medium to which the pigment was mixed; 4) a clay slip or clay + hematite slip has no or very few inclusions, is opaque, and the limit with the body is very well defined. 5) Finally, the uncoated surface of the tiles presented a greater and more intense reduction zone than the coated side. The latter does not allow for as much carbon (not the pigment but the element) penetration because of the finer grain size due to burnishing which promotes surface sealing due to particle floating and alignment. When graphite and charcoal were applied after the bisque firing, but not fired again, the color washed off or weakened, and color penetration was quasi nihil. The experiment when pigments are mixed to mineral oil and not a clay slip are not presented here, but figure $6 \mathrm{~b}$ shows some of these results.

As can be understood, controlling the firing atmosphere and temperature is key to obtaining a true black surface or designs. For the firing process, different options are proposed. De La Fuente et al. (2005) propose a first firing in a reduced atmosphere then a 2nd firing at lower temperature after a slip is applied. Marte et al. (2012) propose three firing possibilities: 1) a mono firing with controlled temperature in oxidizing atmosphere, avoiding transformation of magnetite to hematite to maintain the black on red decoration; 2) a bi-firing: low temperature in oxidizing atmosphere at 500-600 C, then in a reduced atmosphere at c. 700 C. 3) A third hypothesis is to apply the pigment mix and do one oxidizing firing at low temperature. For Andrée Valley, three options can also be envisioned: 1) After reaching optimum temperature, the wares are first reduced as the fire is totally covered (by combustible, dirt, large broken ceramic fragments), then left to cool at which time superficial oxidation or re-oxidation can happen, as the combustible has burned and more air can access the structure. 2) The wares are first quickly fired in neutral atmosphere then reduced in a barrel-like firing. 3) It is also possible to apply a red slip and paint an iron, manganese, or graphite slip on the surface, then fire the vessel in an oxidizing or neutral atmosphere. In this case, a low temperature will not necessarily induce an iron oxide change and the pigments could keep close to their application color. Black iron (e.g. magnetite, $\mathrm{Fe}_{3} \mathrm{O}_{4}$ ) will continue as black at lower temperature, while hematite would turn brown or red-brown (rather than black in reducing atmosphere). Graphite will produce black if the temperature is below $\Delta 014\left(834^{\circ} \mathrm{C}\right)$ and will burn out at about $887^{\circ} \mathrm{C}$. Finally, as seen above, graphitization can also be achieved in reduction-firing. Even then, unless a piece is carbonized so heavily the surface is fully reduced to black, iron reds and darker manganese blacks are obtained in a reduction atmosphere, as well as in atmospheres that have been reduced then re-oxidized. Also, in a barrel-type reduction, only the surface is reduced and it is unusual for the carbon to penetrate deeper. In pit firing conditions, where the firing is long, carbon penetration to the core can be achieved.

As no black core was usually observed in Cupisnique Rojo Grafitado vessels and as these wares display a well-oxidized body it can be proposed that the painted wares were first fired in oxidizing or neutral atmosphere, then were submitted to a short reduction cycle in a tightly closed (barrellike) environment, or one that does not permit re-combustion or re-oxidizing, such as covering the pit kiln with a thick cover with old ashes from past firings. The wares were, not heavily carbonized so the red slip would stay red. If graphite is present, the firing temperature would also have been 

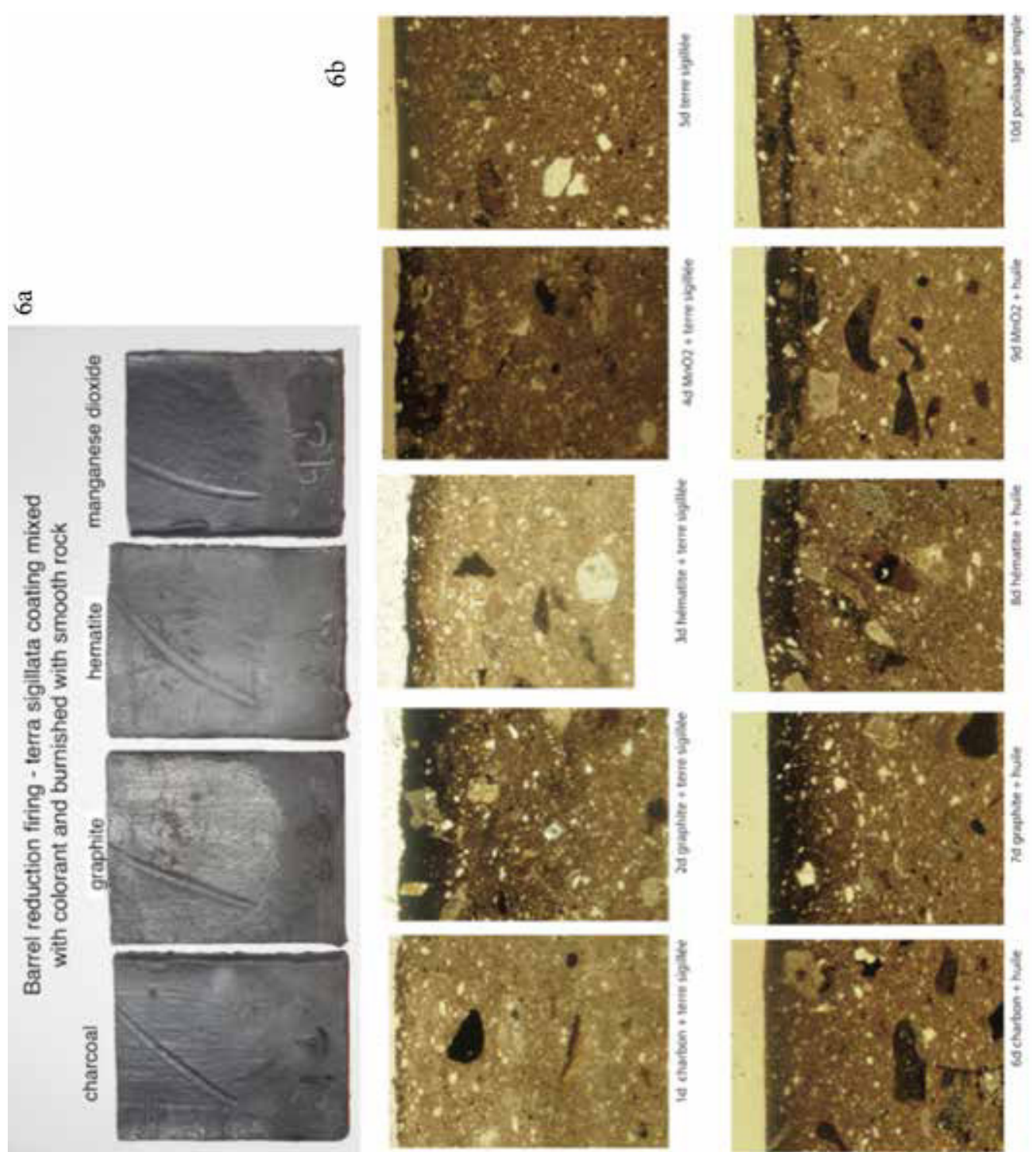

कิ

ริ)

के

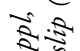

ลี
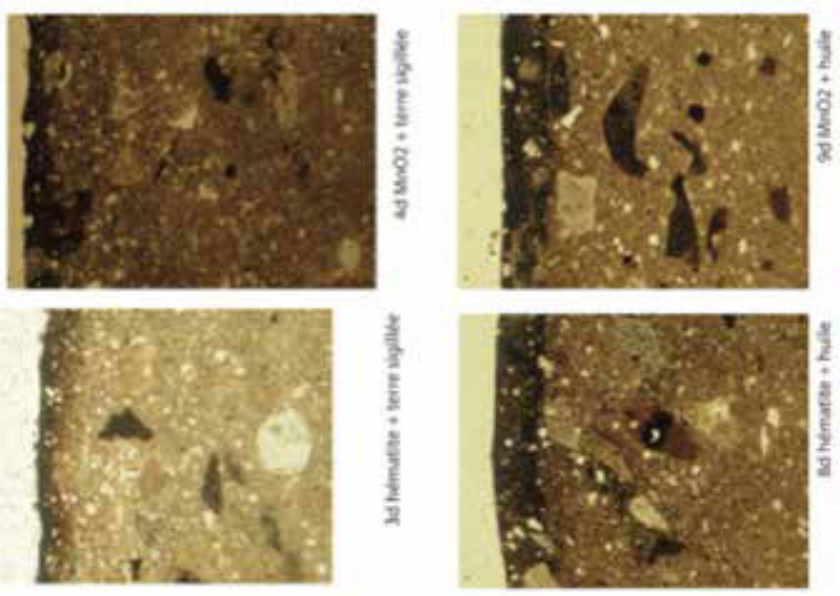

胥

궁ำ

$\therefore 8$

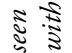

8 ( )

3

है

จ० ฐ

章贺

$\infty$

ज्ञाँ

क्ष

a 3

ह छ

है है
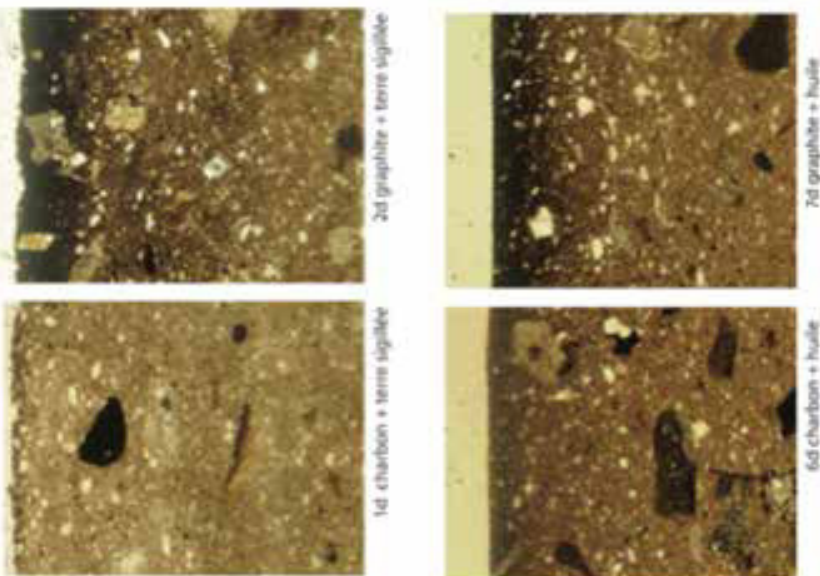

ปูำ ปิ

5ิ

की

ริ

कृ

30

ปิ

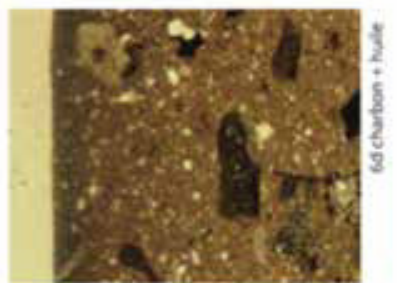

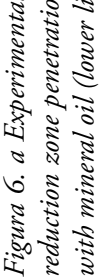


below $834^{\circ} \mathrm{C}$ using graphite as a temperature indicator. For the Puémape bottle with Mn pigment, a neutral or oxidizing firing is also possible as described in Valley's option 2) above.

It is worth mentioning that no significant iron peaks were detected in our analyses, suggesting that the use of iron was not part of the technological tradition for the production of black pigment in the Cupisnique Rojo Grafitado vessels. Iron, however, becomes the preferred material for the black pigment recipes of potters from the Intermediate Period in the same region, as shown in the study by Del-Solar-Velarde and colleagues (this volume). The very low Mn presence detected in some of the Moche and Cajamarca Serrano ceramics could have been added to enhance the iron or be naturally present with the iron oxides used (Dill 2010: 85, 89).

\section{Conclusion}

This study suggests the presence of a technological tradition with workshops specialized in producing stirrup-spout Cupisnique Rojo Grafitado bottles, sharing recipe and technology, and participating in a distribution network that specializes in wares for ceremonial and burial use. Per the type of intrusive rock fragments in their paste, mid-valley production loci are suggested, possibly in the Cupisnique or Jequetepeque Valleys, but also in adjacent valleys where sediments with this type of material are found. Most probably, several workshops or potters in different valleys were involved, as the paste composition of the different fragments examined show compositional variants. Based on analysis data, three production scenarios are plausible: 1 ) the potters were from the same area or community of practice, but traveled, or established themselves in other regions, adapting to the resources at hand, still keeping close to their tradition of using granitic material, and carbon-graphite (as pigment or obtained by carbonization during firing process), or manganese; 2 ) the potters were from different communities, but shared the same technological style, varying the means of achieving it according to local availability; 3) this ware-style being highly codified, the way to produce it might also have been codified. Skilled potters can adapt to technological dictates and produce the wares asked for by their patron or customers, from their home workshop or as itinerant potters. This implies that local potters could have imitated the Rojo Grafitado style, using materials close to the usual ones for this ware type. This may have been the case in Kuntur Wasi during the Kuntur Wasi phase, a time of great expansion and changes for the ceremonial site. Graphite-decorated bottles are special nonlocal productions, while bowls may have been produced as variants of the original Rojo Grafitado wares. Imitation in form and finish is also suggested in the case of well-polished black Middle Sicán vessels, which fetched a high value (Goldstein and Shimada 2007: 47).

Finally, the availability of the ore minerals from which the pigments could be obtained should be considered. Graphite is common and found in metamorphic and igneous rocks (as part of the coastal Batholith), and often where anthracite or coal are present. In addition, ores for pigments could be widely traded. The fact that pigments can have a wider distribution than clay or temper (Arnold 1985) suggests that using a mineral for pigment is a matter of tradition rather than availability. The same is true for paste recipes. The Cupisnique potters responsible for the production of the Rojo Grafitado vessels followed a technological tradition with tight rules that distinguished their products not only in terms of style, but also paste and production.

\section{Acknowledgements}

We are very thankful to Ulla Holmquist and the Larco Herrera museum for allowing the first author to analyze a few of their Cupisnique pieces. This Rojo grafitato study benefitted from data generated by the Kuntur Wasi ceramic analysis project, supported by Saitama University and JSPS KAKENHI Grant number 23401040. The 1997 initial Puémape study was funded by the Social Science Human Research Council of Canada. We are thankful to these funding agencies and institutions for their support. 


\section{Appendix: Mineral composition of the Larco Museum rojo Grafitado bottles analyzed}

Paste analysis conducted in reflective light with digital portable microscope DinoLite.

Abbreviations: $\mathrm{qz}=$ quartz, $\mathrm{fd}=$ feldspath, $\mathrm{pl}=$ plagioclase, $\mathrm{hn}=$ hornblende, $\mathrm{bt}=$ biotite .

ML015449. Stirrup bottle, Barbacoa, Chicama V. 1934, 210 cm H, 771 gr. Iconography: black monkey over red. Formative period. Composition: Medium felsic (qz, abundant $\mathrm{fd}$ and $\mathrm{pl}$ ) and numerous fine mafic crystals, angular to subround medium to coarse rock fragments of acid to intermediate composition (c. $60 \%$ felsic, $40 \%$ mafic) and possible sedimentary clasts. Inclusions are oriented parallel to the wall in a fine granular clay matrix with felsic and mafic crystals. Light brown to pinkish paste, fully oxidized, compact.

ML015450. Stirrup bottle, Barbacoa \#40, Chicama V. 1939, 206 cm H, 663 gr. Iconography: black spiral over red. Formative period. Mineral composition: c. $70 \%$ fine to medium felsic crystals (qz, fd/ $\mathrm{pl}$ ) and c. 30\% fine mafics (bt, hn), two possible plutonic lithoclasts but difficult to assess. Angularsubangular to subround grains. Albeit well sorted, the grains present a mix orientation, with tendency towards parallel alignment seen in the pores and fine elongated minerals Paste is grey brown, with variation in oxidation.

ML015284. Stirrup bottle, Barbacoa \#14, Chicama Valley. $211 \mathrm{~cm} \mathrm{H}$, (broken spout at first third of height. 637 gr. Formative period. Mineral composition: volcanic paste with pyroclasts and felsic phenocryst of fine to coarse size (one coarse pumice? with medium angular pl? phenocryst). Matrix presents fine felsic and mafic crystals. No grain orientation, medium well sorted, not well compacted, reduced paste light to dark grey.

ML015285. Stirrup bottle, Barbacoa \#59, Chicama V. 197 cm H, 463 gr. Formative period. Mineral composition: black pigment, graphite or manganese? Compare with SEM. 140x/160x: paste rich in fine to medium-size amphibole and felsic ( $\mathrm{qz}, \mathrm{fd} / \mathrm{pl}$ ) crystals, mica, minor oxidized grains. Possibly, two plutonic lithoclasts (but surface contamination impedes to see well). Inclusions are mostly angular to subangular, with a minority of subround grains. No grain orientation observed. Paste is granular, light brown, compact, fully oxidized.

ML01589. Stirrup bottle, North coast. $205 \mathrm{~cm} \mathrm{H,} 610$ gr. Formative period. Mineral composition: medium to coarse $\mathrm{qz}$ and $\mathrm{fd} / \mathrm{pl}$ crystals, and fine to medium mafic (possibly amphibole) crystals. Grains are oriented parallel to the wall. Paste matrix is granular with silt to fine sand-size felsic and mafic crystals. Possible polyquartz and/or felsic rock fragment(s). Light brown paste, fully oxidized.

ML015291. Stirrup bottle, Barbacoa, Chicama V. Tomb 23. 1939. $183 \mathrm{~cm} \mathrm{H}$ (spout broken at base), 738 gr. Formative period. Mineral composition: Fine to medium-size felsic (qz and abundant fd-most probably pl), mafic and oxidized grains, few medium probably plutonic lithoclasts of intermediate composition. Brown granular paste, mix grain orientation, compact, fully oxidized. At one place, the circular orientation of the clay, pores and grains suggests the use of a coil.

ML015292. Stirrup bottle, Sta Ana cemetery, tomb 6, 1940. Chicama V. 260 cm H, 826 gr. Formative period. Mineral composition: angular to subangular fine to medium felsic crystals (qz, abundant fd-most probably pl), fine mafic crystals, oxidized round grains. Angular to subangular medium probably plutonic rock fragments of acid to intermediate composition. c. felsic $60 \%$, mafic $40 \%$. Mix grain-orientation in granular clay matrix, but good distribution and well sorted. Light brown paste, fully oxidized, long pores oriented parallel to walls.

ML015294. Stirrup bottle, Barbacoa \#32, Chicama V. 225 cm H, 618 gr. Formative period. Mineral composition: angular to subangular fine to medium felsic crystals (abundant fd-most probably pl), fine mafic crystals, oxidized round grains. Angular to subangular coarse plutonic rock fragments of acid to intermediate composition (with pl, qz, hn?, bt) Photomicrograph at 65x shows at least 10 intrusive lithoclasts. One possible volcanic rounded grain. Very coarse oxidized grains. c. felsic $70 \%$, mafic $30 \%$. Mix grain-orientation in granular clay matrix, but good distribution and well sorted. Brown to red-brown paste, fully oxidized, some long and large pores visible, other areas well compacted. Black pigment on surface $0.25 \mathrm{~mm}$ thick. 


\section{References}

Acevedo, V. J., M. A. López, E. Freire, E. B. Halac, G. Polla and M. Reinoso

2012 Estudio de pigmentos en alfareria estilo negro sobre rojo en la Quebrada de Humahuaca, Jujuy Argentina, Boletín del Museo Chileno de Arte Precolombino 17(2), 39-51. https://doi.org/10.4067/S071868942012000200004

Acevedo, V. J., M. A. López, E. Freire, E. B. Halac, G. Polla, M. Reinoso and F. Marte

2015 Caracterización arqueométrica de pigmentos color negro de material cerámico de la quebrada de Humahuaca, Jujuy, Argentina, Chungará 47 (2), 229-238. https://doi.org/10.4067/S071773562015005000026

Arnold, D.

1985 Ceramic theory and cultural process, Cambridge University Press, Cambridge.

Bertolino, S., V. Galvan Josa, A. Carreras, A. Laguens, G. de la Fuente and J. Riveros

2009 X-ray techniques applied to surface paintings of ceramic pottery pieces from Aguada culture (Catamarca, Argentina), X-ray Spectrometry 38, 95-102. https://doi.org/10.1002/xrs.1124

Bertolino, S. R., V. Galván Josa and G. Castellano G.

2011 Ceramic Surface Paintings and Pigments from the Aguada Culture (Argentina): XRD and SEM-EDX Archaeometric Studies, in: S. M. Sarrica (ed.), Paints: Types, components and applications, chemistry research and applications, 169-211, Nova Science Publishers, New York.

Burtenshaw-Zumstein, J. T.

2014 Cupisnique, Tembladera, Chongoyape, Chavin? A Typology of Ceramic Styles from Formative Period Northern Peru 1800-200 BC, PhD Dissertation, University of East Anglia.

Clark, K.

2001 The potter's manual. Chartwell Books, Edison.

Cremonte, B. M., M. Baldini and I. L. Botto

2003 Pastas y colores. Un camino al conocimiento del estilo Portezuelo de Aguada, Intersecciones en Antropologia 4, 3-16.

De La Fuente G., N. Kristcautzky, G. Toselli and A. Riveros

2005 Petrología cerámica comparativa y analisis composiciional de las pinturas por MEB-EDS de estilo Aguada Portezuelo (ca. 600-900 DC) en el valle de Catamarca (Noroeste Argentino), Estudios Atacameños 30, 61-78. https://doi.org/10.4067/S0718-10432005000200004

Dill, H. G.

2010 The «chessboard» classification scheme of mineral deposits: Mineralogy and geology from aluminum to zirconium, Earth-Science Reviews 100, 1-420. https://doi.org/10.1016/j.earscirev.2009.10.011

Druc, I.

2011 Tradiciones alfareras del valle de Cajamarca y cuenca alta del Jequetepeque, Perú, Bulletin de l'Institut Francais d'Etudes Andines 40 (2), 307-331. https://doi.org/10.4000/bifea.1438

2014 Alfares de Puémape: un análisis petrográfico de cerámicas formativas de la costa norte, Perú, Arqueología $y$ Sociedad 28, 275-288.

Druc, I., K. Inokuchi and L. Dussubieux

2017a LA-ICP-MS and petrography to assess ceramic interaction networks and production patterns in Kuntur Wasi, Peru, Journal of Archaeological Science Reports 12, 151-160. https://doi.org/10.1016/j.jasrep.2017.01.017

Druc I., K. Inokuchi, V. Carlotto and P. Navarro

2017b Looking for the right outcrop, in: M. Ownby, I. Druc and M. Masucci (eds), Integrative approaches in ceramic petrography, 144-156, University of Utah Press, Salt Lake City.

Eerkens J. G. Barfod, K. Vaughn, P. Williams and Ch. Lesher

2014 Iron isotope analysis of red and black pigments on pottery in Nasca, Peru, Archaeological and Anthroplogical Sciences 6 (3), 241-254. https://doi.org/10.1007/s12520-013-0151-6 
Elera, A. C.

1998 The Puémape site and the Cupisnique culture: A case study on the origins and development of complex society in the Central Andes, Peru, PhD Dissertation, Department of Archaeology, University of Calgary, Alberta.

Galvan Josa V., S.R. Bertolino, J.A. Rivero and G. Castellano

2009 Methodology for processing backscattered electron images. Application to Aguada archaeological paints, Micron 40, 793-799. https://doi.org/10.1016/j.micron.2009.07.005

Goldstein, D. J. and I. Shimada

2007 Middle Sicán multicraft production: Resource management and labor organization, in I. Shimada (ed.), Craft production in complex societies: Multicraft and producer perspectives, 44-67, The University of Utah Press, Salt Lake City.

Ikehara, H. and K. Shibata

2005 Festines e integración social en el Período Formativo: nuevas evidencias de Cerro Blanco, Valle bajo de Nepeña, Boletín de Arqueología PUCP 9, 123-159.

Inokuchi, K.

2010 La arquitectura de Kuntur Wasi: secuencia constructiva y cronología de un centro ceremonial del Período Formativo, Boletin de Arqueología PUCP 12, 219-248.

Larco Hoyle, R.

1941 Los Cupisniques, Congreso International de Americanistas de Lima, Sesión XXVII. Editorial La Crónica, Lima.

Lumbreras, L. G.

1993 Excavaciones en el templo antiguo de Chavin (sector R). Informe de la sexta campańa. Nawpa Pacha, Journal of Andean Archaeology 15 (2), 1-38. https://doi.org/10.1179/naw.1977.15.1.001

Marte, F., V. Acevedo and N. Mastrangelo

2012 Técnicas arqueométricas combinadas aplicadas al análisis de diseños de alfarería «tricolo aroposes al

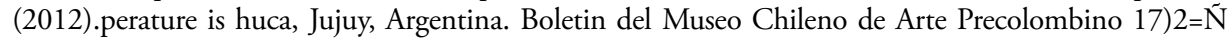
53'64.perature is r», de Quebrada de Humahuaca, Jujuy, Argentina, Boletin del Museo Chileno de Arte precolombino 17 (2), 53-64. https://doi.org/10.4067/S0718-68942012000200005

Nesbitt, J.

2012 Excavations at Caballo Muerto. An investigation into the origins of the Cupisnique culture, PhD Dissertation, Yale University, New Haven.

Onuki, Y. and K. Inokuchi

2011 Gemelos prístinos. El tesoro del templo de Kuntur Wasi, Fondo editorial del Congreso del Perú/Minera Yanacocha, Lima.

Puente, V. , P. M. Desimone, J. P. Tomba and J. M. Porto López

2017 Compositional variability of pigments of Belén-style prehispanic ceramics from el Bolsón Valley, Catamarca Province, Argentina, Journal of Archaeological Science Reports 12, 553-560. https://doi. org/10.1016/j.jasrep.2017.03.007

Sepulveda, M., D. Valenzuela, L. Cornejo, H. Lienqueo and H. Rousselière

2013 Óxidos de manganeso en el extremo norte de Chile: abastecimiento, producción y movilidad del color negro durante el período arcaico, Chungará 45 (1), 143-159. https://doi.org/10.4067/S071773562013000100007

Shepard, A.

1968 Ceramics for the archaeologist, Carnegie Institution of Washington, Washington, D.C.

Shimada, I., C. G. Elera, V. Chang, H. Neff, M. Glascock, U. Wagner and R. Gebhard

1994 Hornos y producción de cerámica durante el Período Formativo en Batan Grande, Costa Norte del Perú, in: I. Shimada (ed.), Tecnología y organización de la producción de cerámica prehispánica en los Andes, 67119, Fondo Editorial PUCP, Lima. 
Shimada, I. and U. Wagner

2001 Peruvian Black Pottery production and metal working: A middle Sicán craft workshop at Huaca Sialupe, Materials Research Society Bulletin 26 (1), 25-30. https://doi.org/10.1557/mrs2001.15

Sidoroff, M.-L.

2005 The process behind form and decoration: Defining North Coast ceramic technological style, Peru, PhD Dissertation, Union Institute and University Cincinnati, $\mathrm{OH}$.

Toshihara, K.

2002 The Cupisnique culture in the Formative period world of the Central Andes, Peru, PhD dissertation, University of Illinois at Urbana-Champaign, IL.

Valley, A. and I. Druc

2017 Experimental replication of black pigment on Andean ceramics. What's left after firing?, Colloque d'archéométrie du GMPCA, Rennes, France.

Wagner, U., R. Gebhard, E. Murad, J. Riederer, I. Shimada, C. Ulbert, F. E. Wagner and A. M. Wippern

1994 Condiciones de cocción y características de composición de la cerámica formativa: Perspectiva arqueométrica, in: I. Shimada (ed.), Tecnología y organización de la producción de cerámica prehispánica en los Andes, 121-156, Fondo Editorial PUCP, Lima.

Recibido: 31/01/2019

Aceptado: 31/07/2019 